\title{
Motivation for Teaching Students at a University: The Ecologization of Pedagogical Communication as a Methodological Technique
}

\author{
Agienko M. I. \\ Ardahan University, Faculty of Humanities and Letters \\ Department of Russian Language and Literature \\ E-mail: marinaagienko1@gmail.com \\ Karpenko O. P. \\ Ardahan University, Faculty of Humanities and Letters \\ Department of Russian Language and Literature \\ E-mail: olenakarpenko@ardahan.edu.tr \\ Kirli Emre \\ Ardahan University, Faculty of Humanities and Letters \\ Department of Russian Language and Literature \\ E-mail: emrekirli@ardahan.edu.tr
}

\begin{abstract}
One of the ways of increasing the educational motivation of students called by the authors the method of pedagogical discourse «greening», which means the ability of the pedagogue to organize the meaning part of his speech, giving it the ability to awaken the student's propensity to develop an optimistic attribute style. The verbalization of some pedagogical tactics, considered in the scientific literature as tactics increasing the educational motivation of students - praise, censure, encouragement etc. are assessed from the point of view of compliance with the optimistic standard.

The Pedagogical Speech Assessment Method has been applied for the first time in this work and includes the evaluation of the life events attribution of M. Seligman (personalization/control locus, stability/permanence and generalization). Emotional features that make it difficult to communicate between teachers and students - the prevalence of negative emotions, low emotional control - are considered in the context of the theory of learned helplessness and learned optimism by M. Seligman. The demotivational potential of learned helplessness and the motivational potential of optimism are described in the paper.
\end{abstract}

Key words: motivation, learned helplessness, optimism, pedagogical tactics, pedagogical strategy, locus of control, explanatory style

DOI: $10.7176 /$ JSTR/6-05-05

\section{Мотивация к обучению студентов в вузе: экологизация педагогического общения как методический прием}

\begin{abstract}
Аннотация
В работе рассматривается один из приемов повышения мотивации студентов к обучению, названный авторами приёмом «экологизации педагогического дискурса», который заключается в умении педагога организовывать смысловую часть собственной речи, придавая ей способность пробуждать склонность студента к формированию оптимистического атрибутивного стиля. С точки зрения соответствия оптимистическому стандарту оценены речевые актуализации некоторых педагогических тактик, рассматриваемых в научной литературе как тактики, повышающие учебную мотивацию студентов, - похвала, порицание, поощрение, подбадривание и др.
\end{abstract}


Метод оценки экологичности педагогической речи впервые применен в данной работе и включает оценку высказывания по параметрам атрибуции жизненных событий М. Селигмана (персонализации/локусу контроля, устойчивости/постоянству и генерализации). Эмоциональные особенности, приводящие к затруднению коммуникации между преподавателями и студентами преобладание негативных эмоций, низкий эмоциональный контроль, - рассматриваются в контексте теории состояний выученной беспомощности и выученного оптимизма М. Селигмана. Описывается демотивационный потенциал состояния выученной беспомощности и мотивационный потенциал оптимизма.

Ключевые слова: мотивация, выученная беспомощность, оптимизм, педагогическая тактика, педагогическая стратегия, локус контроля, атрибутивный стиль

\section{Введение}

Актуальность данной статьи определяется особенностями ситуации, связанной с упрощением механизма дифференциации абитуриентов при поступлении в высшее учебное заведение, имеющей место в настоящее время в образовании многих стран мира. Это приводит к тому, что в вузы приходят слабо мотивированные на обучение студенты - бывшие интеллектуально пассивные школьники и школьники с общим отставанием в обучении. Педагог должен быть готов к работе с подобного рода студентами до того, как возникнет «эффект сообучения» и им удастся негативно повлиять на общий уровень мотивации студентов в учебной группе и вузе.

Обучение в группе студентов с разной мотивацией сложно для педагогов по нескольким причинам. Во-первых, преподаватели высшей школы в массе своей - люди, мотивированные на получение знаний, - в силу специфики собственной мотивации, облегчающей понимание «себе подобных», испытывают затруднения при понимании проблем «иномотивированных» студентов.

Во-вторых, преподаватели вузов, вносящие основной вклад в специальную профессиональную подготовку, имеют специальное профессиональное образование - медицинское, техническое, юридическое и т.д. Не у всех преподавателей высшей школы, не имеющих базового педагогического образования, сформирована психолого-педагогическая компетенция и особенно мотивационная установка на использование психолого-педагогических знаний. Процесс обучения эти преподаватели выстраивают либо «по наитию», либо копируя стиль своих коллег или преподавателей, обучавших их во время их ученичества. Модели поведения такого педагога, выбранные интуитивно или сознательно, но без учета психолого-педагогических знаний, неизбежно опираются на особенности его личности - как на достоинства, так и недостатки, некоторые из которых, возможно, противопоказаны профессии педагога, например, эмоциональная глухота, авторитарный стиль общения, склонность к вербальной агрессии и т.д.

В-третьих, большая часть преподавателей - приверженцы генетической природы способностей традиционно объясняют слабые учебные успехи студентов отсутствием врожденных способностей к предмету, а не сниженной мотивацией. В результате мотивированность к учебной деятельности большинства студентов после их поступления в высшее учебное заведение не всегда профессионально корректируется, и студенты, столкнувшись с первыми трудностями обучения, зачастую полностью утрачивают мотивацию к учебному процессу, замещая её на мотивацию к получению диплома о высшем образовании. На выходе мы получаем скучающего специалиста с довольно посредственным уровнем знаний, не интересующегося впоследствии высокопрофессиональным решением рабочих задач.

Наконец, проблема профессиональной коррекции учебной мотивации при формировании специалиста имеет и валютное измерение. По подсчетам А.Валеро и Дж. ван Реена, увеличение числа университетов в стране со временем трансформируется в экономический рост государства. По статистике, проведенной учеными, каждый вновь открывшийся университет через некоторое время повышает объем экономики своего региона на 0,4\%, а объем ВВП всей страны - на 0,05\% [Valero A., Van Reenen J., 2019]. Поэтому можно сказать, что повышение учебной мотивации студента к овладению им профессиональными знаниями - вопрос экономической важности для любой страны.

Метод

Одной из причин низкой учебной мотивации студентов считается сниженный уровень психологического благополучия (д-р психол. наук Т. О. Гордеева). В качестве основного фактора,

49 | $\mathrm{P}$ a g e

www.iiste.org 
препятствующего становлению психологического благополучия личности студента, рассматривается состояние выученной беспомощности (д-р психол. наук О.В. Волкова, д-р психол. наук Д.А. Циринг $2001,2010)$, которое лежит в основе пессимистических взглядов на жизненные события и связанного с ним мотивационного дефицита. В работах М. Селигмана пессимистическое восприятие противопоставляется оптимистическому восприятию событий как особому стилю объяснения успехов и неудач, особенно его положительным мотивационным характеристикам. Учёный утверждает, что оптимизму можно и нужно учить в любом возрасте. Более того, сознательно приобретенный оптимизм будет нести все те же позитивные последствия, в том числе и мотивационные, что и оптимизм, усвоенный от родителей с детства.

В данной работе рассматривается прием, названный авторами приёмом «экологизации педагогического дискурса» как один из способов привития студенту оптимистического восприятия учебных событий. Он заключается в умении педагога организовывать смысловую часть собственной речи, придавая ей способность влиять на эмоции студента и стимулировать те из них, которые необходимы для улучшения психологического состояния студента: повышать устойчивость его психики к формированию беспомощности, пробуждать склонность к формированию оптимистического атрибутивного стиля.

Для оценки соответствия педагогической речи оптимистическому стандарту применяется метод оценки экологичности речи. Он подразумевает оценку определенного высказывания по параметрам атрибуции жизненных событий M. Селигмана (персонализации/локусу контроля, устойчивости/постоянству и генерализации), а также опирается на методику «определения степени выраженности оптимизма/пессимизма в речи говорящего» [см.: А.В. Пузырев\& Ю. В. Капрянцева 2016, С.А.Байшева, 2005; Ю.В.Котова, 2012, 2013, 2013-а].

Максимальная негативность фразы может иметь показатель «минус 5» (отрицательная негативность по всем параметрам оценки), максимальная позитивность - «плюс 5» (положительная эмоциональная нагруженность высказывания по всем параметрам).

В работе оценены возможные речевые актуализации некоторых педагогических тактик, рассматриваемых в научной литературе как тактики, повышающие учебную мотивацию студентов, похвала, порицание, поощрение, подбадривание и др. [см. М. Н. Крылова, М. И. Агиенко\&А.А. Рольгайзер].

Теоретико-методологической базой исследования послужили работы М. Селигмана по позитивной психологии (выученному оптимизму и выученной беспомощности), межличностная теория мотивации и атрибутивная теория мотивации и эмоций Б. Вайнера, теория локуса контроля и теория социального научения Дж. Роттера.

\section{Обзор литературы по теме}

Мотивация к обучению (учебная мотивация) как аспект продуктивности деятельности, наряду с игровой и трудовой деятельностью человека, входит в круг проблем, изучаемых педагогикой, психологией мотивации, педагогической психологией и др.

Педагогика связывает вопросы формирования устойчивой учебной мотивации с дидактическими принципами составления учебного материала, выстраивания учебной деятельности, объективности, систематичности контроля в учебном процессе, вопросами стиля педагогической деятельности преподавателя. Приемам создания благоприятного психологического климата как неотъемлемому условию формирования мотивации к учению в педагогической литературе уделяется большое внимание начиная с трудов Яна Амоса Коменского. Великий педагог еще в 17 веке писал: «Дай человеку понять: 1) что он по своей природе хочет того, стремление к чему ты ему внушаешь, - и ему сразу будет радостно хотеть этого, 2) что он от природы может иметь то, чего желает, - и он сразу обрадуется этой своей способности» [Коменский: 428].

На сегодняшний день педагогическими трудами Л.Н. Толстого, К.Д. Ушинского, А.С. Макаренко, В.А. Сухомлинского, Ш.А. Амонашвили, А.С. Белкина сформировалось научное направление педагогика сотрудничества, генеральной линией которой является чувственное формирование личности учащегося и эмпатия преподавателя. Основными параметрами эффективного поведения учителя определяются обаяние, любовь к детям, доброжелательность, искренность, умение общаться и т.д.

Вынуждены констатировать, что все педагогические труды о важности эмпатии и позитивной эмоциональности в работе педагога отличаются полным доверием педагогу в том, что его

50 | P a g e

www.iiste.org 
педагогическое мастерство позволит ему профессионально овладевать методами создания благоприятного психологического климата на занятии и априори допускают, что «глубокие и обширные философские и психологические истины», о которых писал еще К.Д. Ушинский, свойственны педагогу на основании его профессиональной принадлежности, что на самом деле не выводится одно из другого. Недавнее исследование по изучению эмоциональных характеристик педагога показало, что 76\% педагогов имеют эмоциональные затруднения, которые мешают устанавливать эмоциональные контакты с учащимися и осложняют межличностное взаимодействие. Основными причинами нарушений у педагогов являются неадекватное проявление эмоций; негибкость, неразвитость, невыразительность эмоций; преобладание негативных эмоций и др. [Верхозина: 416].

Психология мотивации занимается вопросами природы мотивационных явлений (А. Маслоу), картиной мира личности, смысловыми связями как основой мотивационных процессов (А.Н. Леонтьев), моделями волевой регуляции деятельности (Д.А. Леонтьев), поведением человека в контексте социальных ситуаций (Дж. Роттер), ответственности самого человека в нарушении его поведения (А. Бандура, Э. Деси, Р. Райан) и др. Результаты исследований в области психологии мотивации по изучению психических процессов, лежащих в основе поведения личности, причин и регуляторов его поведения имели бы большую объяснительную силу для решения проблем в практической деятельности педагога, если бы не сложность научной терминологии для читателянеспециалиста в области психологии и не традиционная вера преподавателя в собственный жизненный опыт и интуицию.

Педагогическая психология изучает процессы учения с точки зрения его природы и закономерностей и использует полученные знания для совершенствования педагогической практики. Одними из ключевых вопросов педагогической психологии являются вопросы соотношения мотивационных и интеллектуальных планов учения, возможности управления этими процессами, диагностики и формирования мотивов учения (Л. С. Выготский, В. В. Давыдов, Л.Н. Леонтьев, К Левин, Л. Фестингер и др.). Прикладная педагогическая психология, на наш взгляд, ближе всего подошла к вопросу зависимости мотивации к учению от эмоций обучающегося. Понимание процесса учения как установления и упрочения связи между стимулом и реакцией (главным образом учеными бихевиористского направления), приводит к пониманию того, что, согласно закону эффекта, отрицательные переживания неуспеха, разочарования и др. разрушают образовавшиеся нейронные связи и не способствуют образованию новых. Это значит, что эффективность учения невозможна без подкрепления, то есть без положительных эмоций, испытываемых учащимися от выполнения учебной деятельности (Э. Торндайк, К. Халл, Р. М. Грановская\&Ю.С. Крижанская, А. К. Маркова и др.).

В последнее время вопросами прикладной педагогической психологии заинтересовались филологи. Пользуясь теоретическими достижениями психологии и, в частности, педагогической психологии, они пытаются совершенствовать вербальную сторону педагогической практики: исследуют и описывают речевые средства гармонизации педагогического дискурса (О.А. Гудина, Т.А. Скворцова, Ю.В. Щербинина и др.); разрабатывают рекомендации по улучшению экологичности педагогического общения (М.И. Агиенко\&А.А. Рольгайзер, Н.А. Антонова, Е.А. Казанцева, В.В. Леонтьев и др.).

Проблематика экологичности педдискурса в работах, выполненных филологами, находится на стыке интегративного подхода психологии (принцип позитивности, В. В. Козлов, 2014) и лингвоэкологии («способность языка влиять на реальные жизненные события», Е.Н. Сердобинцева, 2008). Психологопедагогические исследования, выполненные на лингвистическом материале, используют терминологию смежных с лингвистикой дисциплин - «дискурс» из работ по концептуальным исследованиям (В.И. Карасик, М. Ю. Олешков и др.) и «экологичность» из лингвоэкологии. В работах по лингвоэкологии категория «экологичность» пересекается, с одной стороны, с категорией (не)вежливости - отсутствием направленности на унижение, оскорбление и эмоциональное травмирование адресата (В.И. Шаховский, Т. В. Ларина и др.), с другой стороны, с оптимистичностью высказывания (А.В. Пузырев, Ю.В. Котова, М.И. Агиенко и др.).

В данной работе под термином «экологизация» понимается осознанная вербальная организация речи педагога с учетом особенностей психологического состояния участников дискурса, направленная на создание благоприятной учебной атмосферы, дающей обучающимся опыт «успеха и радости». Под дискурсом понимается «специализированная клишированная разновидность коммуникации» между

$\mathbf{5 1}$ | P a g e

www.iiste.org 
основными участниками общения (учитель-ученик), отличающимися принципиальным неравенством по положению, возрасту и уровню образования» [Карасик: 5].

Под мотивацией традиционно понимается «совокупность всех факторов, механизмов и процессов, обеспечивающих возникновение побуждений к жизненно необходимым целям, т.е. направляющих поведение на удовлетворение потребностей» [Успенский, Чернявская].

\title{
Результаты исследования
}

\author{
«Mы не говорим педагогам - поступайте так или иначе; \\ но говорим им - изучайте законы тех психических явлений, \\ которыми вы хотите управлять, \\ и поступайте, соображаясь с этими законами \\ и теми обстоятельствами, \\ в которых вы хотите их приложить» \\ (К. Д. Уиинский)
}

Связь учебной мотивации студента со стилем педагогического общения утверждалась и классиками педагогики (В. А. Сухомлинский) и психологии (Д. Н. Узнадзе) и доказана экспериментальными исследованиями современных психологов [см., например, Р. И. Цветкова].

Роль эмоций в формировании учебной мотивации

Согласно атрибутивной теории мотивации и эмоций Бернарда Вайнера, линия эффективного поведения начинает выстраиваться с эмоциональной оценки (в нашем случае - учебного результата), которая заставляет человека искать причинное объяснение произошедшему (внутренними или внешними причинами), что, в свою очередь, вызывая специфические эмоции (гордость за способности или стыд неудачи), предопределяет мотивационные ожидания и, как следствие, поведение. Схематично процесс нахождения наиболее приемлемого поведенческого решения выглядит следующим образом: событие (например, неудача на экзамене) $\rightarrow$ эмоциональная реакция на результат $\rightarrow$ причинное объяснение произошедшему $\rightarrow$ психологические последствия (будущие ожидания, эмоциональные состояния) $\rightarrow$ поведение. Теория Б. Вайнера объясняет, каким образом эмоциональный отклик даже на отдельную учебную ситуацию может повлиять на мотивационный уровень к учению.

Развивая межличностную теорию мотивации, Б. Вайнер утверждал, что эмоциональное состояние человека складывается из эмоциональных реакций на поведение окружающих его людей сверстников, родителей, преподавателей - и меньше поддается его собственному контролю. Поиск причинного объяснения произошедшему, согласно его теории, осуществляется не только самим обучающимся, но и наблюдателем (воспитателем, преподавателем или родителем). Наблюдатель (преподаватель в контексте нашей статьи) находит причинный фактор, параметры которого могут соответствовать или не соответствовать параметрам причины, найденной обучающимся. Затем преподаватель делает вывод о студенте и выстраивает свое поведение в соответствии со своим выводом, что вызывает определенные ответные эмоциональные реакции студента, которые влияют на его учебную мотивацию. Например, преподаватель, который определяет «усилие» как внутренний, контролируемый параметр, может в конечном итоге рассердиться, сделать выговор студенту, который ранее разочаровался в эффективности своих усилий и убежден в неконтролируемости параметра «усилие», и тем самым снизить и без того довольно низкую мотивацию учебную мотивацию студента.

Теория внешних и внутренних факторов, к которым апеллирует человек при объяснении событий своей жизни, была расширена теорией локуса контроля Джулиана Роттера. Склонность приписывать результаты деятельности внешним факторам он назвал внешним локусом контроля (экстернальностью), склонность приписывать результаты деятельности внутренним факторам «внутренним локусом контроля» (интернальностью). Внешними факторами служат неудачно сложившиеся обстоятельства: организация учебного процесса, особенности образовательного учреждения и т.П., внутренними факторами являются свойства личности индивида: свои усилия,

52 | P a g e

www.iiste.org 
собственные положительные и отрицательные качества, наличие или отсутствие необходимых знаний, умений и навыков и т. п.

Е.М. Андерман, С.А. Уолтерс подчеркивают, что если фактором внутреннего контроля объясняется положительный учебный опыт, студент испытывает гордость за себя, имеет высокую самооценку, настойчив в достижении поставленной цели, уравновешен, доброжелателен. Если фактором внутреннего контроля объясняется негативный учебный результат, студент испытывает стыд и безнадежность, не уверен в себе, тревожен, неуравновешен. Оптимальным является внутренневнешний локус контроля, который предполагает экстернальность в области причин неудач (Был не мой день!) и интернальность в области преодоления неудач (Я могу исправить эту ошибку!).

Психологические проблемы студента как фактор снижения учебной мотивации

Проводя психологические эксперименты над животными, Мартин Селигман обнаружил, что иная комбинация локуса контроля (интернальность в области причин неудач/ Я неудачник! и экстернальность в области преодоления неудач/ Если повезет, все получится!) приводит к своеобразной поведенческой модели. Собаки, которые в экспериментах М. Селигмана подвергались слабым ударам тока без возможности изменить неприятную для себя ситуацию, не пытались предпринять никаких мер даже тогда, когда они могли избежать ударов током, просто выйдя из клетки. Выводы, сделанные М. Селигманом из результатов эксперимента, явились поворотным моментом в истории психологии мотивации. Ученый назвал состояние, при котором человеку кажется, что внешние события от него не зависят и он ничего не может сделать, чтобы их предотвратить или видоизменить, выученной беспомощностью. Понятие «выученной беспомощности» связано с неадекватной пассивностью и снижением мотивации человека в проблемной ситуации, с приобретенным нежеланием избегать травматического воздействия после неоднократного повторения неудачных попыток его контролировать. Состояние выученной беспомощности также тесно связано с невозможностью быстро дезактивировать мысли о неудаче, которые, оставаясь в активном состоянии, поглощают ресурсы, необходимые для реализации намерения.

Последующие исследования М. Селигмана и Д. Хирото показали, что состояние выученной беспомощности имеет тенденцию к распространению на все более широкий спектр ситуаций и постепенно становится моделью поведения. Также ими было выявлено, что беспомощности можно научиться, наблюдая за «беспомощным» поведением других людей. То есть обучить беспомощности может семья, друзья или учителя, демонстрируя беспомощное поведение или делясь пессимистическим видением причины своих неудач [Hiroto 1974: 187; Hiroto, Seligman: 311 ]. Феномен выученной беспомощности ведет к мотивационному дефициту (пониженной инициативе и пониженной настойчивости), познавательному дефициту (неспособности воспринимать благоприятные возможности для контролируемых результатов) и эмоциональным дефицитам (унынию и сниженному самоуважению). Все перечисленные дефициты вызывают внутренний дискомфорт, ощущение ущербности, беспомощности. М. Селигман и Дж. Вейсс, применив методику анализа дневниковых записей пожилых людей, обнаружили что реакция на неблагоприятные факторы их жизни оставалась неизменной на протяжении всей жизни (результаты показали, что реакции оставались устойчивыми в течение 52 лет) [цит. по: Геранюшкина, Афраймович, 2013: 18]. Выученная беспомощность может появиться как результат на травмирующие неподконтрольные события в жизни человека в любом возрасте, но обычно она формируется в школьные годы и ко времени студенчества становится привычным состоянием.

Тяжесть переживания своей беспомощности и сопутствующих ей дефицитов заставляет человека подсознательно прибегать к психологической защите - компенсации, вытеснению, интеллектуализации и др. [Геранюшкина, Афраймович, 2014]. Использование этих защитных психологических механизмов само по себе в конечном счете имеет негативное влияние на течение состояния выученной беспомощности, а формы их проявления часто заслуживают порицания [Геранюшкина, Афраймович, 2014].

Так, чтобы снизить чувство внешне немотивированной тревоги, человек, страдающий комплексом выученной беспомощности, избегает субъективно сложных задач и заданий, любого внешнего контроля. Чтобы «нейтрализовать внутренний эмоциональный «паралич» и чувство оцепенения, которые возвращают к детской незащищенности» [Геранюшкина, Афраймович, 2014: 26], он может

53 | P a g e

www.iiste.org 
провоцировать или предпочитать участвовать в конфликтных ситуациях, дающих ему внешние стимулы. Чтобы повысить чувство самодостаточности в собственных глазах, человек может собственные мало одобряемые чувства и качества (агрессивность, недоброжелательность и др.) приписывать окружающим. Чтобы избежать конфликта или поддержать высокую самооценку, может на словах присваивать себе достоинства или положительные поведенческие характеристики другого человека, не делая их частью собственной личности и т.д. Временно предпринятые меры способствуют самоуспокоению, но привычное чувство печали и низкая самооценка страдающего выученной беспомощностью человека всегда возвращают его в пессимистическое состояние духа. Количество студентов с симптомами выученной беспомощности довольно велико. Многочисленные исследования на наличие признаков выученной беспомощности показывают, что группу участников эксперимента, не имеющих признаков беспомощности, обычно составляют 10-12\% участников тестирования, процент носителей отчетливых признаков выученной беспомощности в разных группах интервьюируемых колеблется от $25 \%$ до $72 \%$. Остальные участники составляют группу с промежуточными, смешанными показателями.

Как видим, выученная беспомощность не может рассматриваться как психологическое состояние, не играющее никакой существенной роли в учебной мотивации студента, так как она существенным образом меняет модель его поведения. Студенты с признаками выученной беспомощности пессимистично настроены, остро реагируют на неудачу, ранимы, не уверены в себе, замкнуты. Они менее настойчивы в достижении цели, чем «самостоятельные» студенты, стараются брать на себя как можно меньше ответственности, на занятиях чаще дают очевидные и тривиальные ответы, склонны к избеганию неудач, поэтому выбирают либо очень легкие задания, либо очень трудные, но лишь для того, чтобы подтвердить собственную неуспешность.

Очевидно, что выученная беспомощность является одной из основных причин снижения учебной мотивации студентов, их интеллектуальной пассивности и общего отставания в обучении, проявившимся еще в школьные годы. Следовательно, одним из способов повышения учебной мотивации может стать повышение внутреннего психологического благополучия обучающегося.

\section{Мотивационные преимущуества оптимизма}

Развивая теорию выученной беспомощности, М. Селигман выделил два стиля объяснения неудач оптимистический и пессимистический. Дальнейшие исследования М. Селигмана и его коллег позволили выявить колоссальные различия между теми, кто реагирует на неприятности как оптимист, и теми, кто прибегает к пессимистическому объяснительному стилю. «Человек, имеющий оптимистический атрибутивный стиль, верит, что неприятности временны, происходят только в одной сфере жизни и виной тому внешние обстоятельства, позитивные же события имеют постоянный характер, происходят в разных сферах жизни, и причиной тому - сама личность. Человек с пессимистическим стилем атрибуции полагает, что неприятности будут длиться вечно и происходить во всех сферах жизни, причем винит он в происходящем себя, хорошее для него временно, случается только в ограниченной области жизни благодаря стечению обстоятельств» [Циринг, Эвнина].

Оптимистов отличает проявление ответственных действий, высокая познавательная активность в целом, любознательность, инициативность, настойчивость, энергичность, деловая результативность, стремление к анализу затруднений, возникающих при реализации стремлений, а также физическое здоровье. Компонентами оптимизма признаются приподнятое настроение, переживание положительных эмоций, юмор.

M. Селигман утверждает, что студенты с оптимистическими взглядами на жизнь учатся намного лучше студентов-пессимистов. Студенты-оптимисты жизнерадостны, ориентированы на успех, демонстрируют высокий мотивационный настрой на учебную деятельность, в основе которого вера в творческие, интеллектуальные силы и возможности. Их привычные позитивные оценки исключают самоуничижение, а также унижение других людей. Эти студенты обычно составляют группы наиболее мотивированных к учению и легко адаптирующихся к академической обстановке студентов. Изучая склонность людей к оптимистическому или пессимистическому взгляду на события жизни, М. Селигман заметил, что пациенты «проговариваются» о своем мировосприятии. Способ описания жизненных событий ученый назвал «стилем объяснения» и определил его характеристики, которые он назвал параметром персонализации, параметром широты в пространстве и параметром постоянства. Оптимистичный стиль мышления, по М. Селигману, объясняет успехи следствием

54 | P a g e

www.iiste.org 
собственных усилий, а не делом случая (параметр персонализации позитивный), уверен, что при желании он сможет добиться успеха в любых обстоятельствах, а не только в лучших условиях (параметр широты в пространстве), убежден, что в будущем он сможет быть успешным, как было всегда, а если момент времени будет не совсем удачным, будет предпринимать попытки, пока не добьется своего (параметр постоянства) [Селигман 2013-а]. Пессимистичный стиль мышления, как считает М. Селигман, полагает, что успех сложился по воле случая, а неудачи в его жизни закономерны (параметр персонализации негативный), просто он случайно оказался в нужном месте (параметр локализации в пространстве) в нужное время (параметр локализации времени), при других обстоятельствах и времени его ждала бы только неудача.

М. Селигман заметил, что пессимисты опускают руки при неприятности не потому, что неприятность так велика, а потому, что они «дают неприятностям самое обобщенное толкование» [Селигман 2006: 127], например, «все преподаватели несправедливы; я неприятен людям; книги бесполезны» В то же время оптимисты «подыскивают любой неудаче конкретное объяснение, в остальном стараясь жить как ни в чем не бывало». Например, «преподаватель Селигман несправедлив; я неприятен этому человеку; эта книга бесполезна» [там же].

Заставить или предложить человеку стать оптимистом и таким образом повлиять на его мотивацию невозможно. Но «на беспомощность можно воздействовать интернальными инструкциями» [Ромек: 85], приучив человека к мысли, что его учебные усилия контролируемы и могут быть способом преодоления неудач, а неудачи могут быть временны, и их причины не генерализованы, а конкретны. Подобные рассуждения побудили нас предпринять попытку оценить речь педагога на предмет того, какой стиль объяснения - оптимистический или пессимистический - демонстрирует преподаватель: заставляет ли он студента смотреть на себя из привычного пессимистического состояния беспомощности или предлагает оптимистическое видение ситуации.

Анализ педагогических стратегий с точки зрения их эффективности в повышении мотивации студента

Мы в своей работе проводим оценку эмоциональной нагруженности реплики преподавателя и пытаемся спрогнозировать возможную интерпретацию речи преподавателя студентом, исходя из его миропонимания и особенностей восприятия при условии, что он находится в состоянии выученной беспомощности.

Прогноз эмоциональной реакции (поведения) на реплику преподавателя мы считаем возможным, основываясь на формуле Дж. Роттера

потенциал поведения = ожидание + ценность подкрепления [цит. по: Зинглер, Хьелл: 272],

где ожидание рассматривается как «генерализованное ожидание», диктуемое локусом контроля индивида, а иенность подкрепления, по Роттеру, соотносится с мотивацией, характер которой нам известен из литературы по проблемам выученной беспомощности.

Знак эмоциональной нагруженности реплики определялся по общей семантике фразы. За образец положительной эмоциональности берется оптимистическая атрибуция событий - экстернальность причины неудач (например, «Задание было нечетко сформулировано!»), интернальность в преодолении неудач (например, «Вы можете преодолеть неудачу самостоятельно!»), локальность неудачи во времени (например, «При определенных условиях в следующий раз вы сможете справиться с заданием!»), локальность неудачи в пространстве (например, «Если задание будет сформулировано четко, вы легко его выполните!»). В таблице эти параметры выделены жирным шрифтом. За образец отрицательной эмоциональности берутся совпадения с параметрами пассивной атрибутивности.

Негативная эмоциональная нагруженность по каждому из параметров обозначается знаком минус «». Позитивная эмоциональная нагруженность - знаком плюс «+». Отсутствие маркеров эмоциональной нагруженности во фразе отмечается знаком «0». Оценивание высказывания производится по четырём параметрам - «локус контроля причины неудач», «локус контроля в преодолении неудач», параметр постоянства (широко или локально во времени), параметр генерализации (широко или локально в пространстве).

Во всех примерах оценена атрибуция «наблюдателя». Реплики снабжены возможными комментариями с точки зрения адресата высказывания (студента), исходя из знания его психологических особенностей.

55 | P a g e

www.iiste.org 
Так, локус контроля причины неудач во фразе преподавателя «Вам следует научиться правильно распоряжаться своим временем!» лежит в интернальной области, так как означает, «вы не умеете правильно распоряжаться своим временем», получая минусовую оценку. Локус контроля в области преодоления неудач лежит в интернальной плоскости с точки зрения наблюдателя, который считает, что усилия в отношении эффективной траты времени являются контролируемым фактором. Но адресат реплики предположительно находится в состоянии выученной беспомощности: обладает бедным поведенческим репертуаром, низкой самооценкой своей способности справиться с проблемой и желанием сохранить положение дел неизменным. Он понимает эту реплику как намек на его недостаток, который теоретически имеет постоянный характер (Я не умею и никогда не научусь), равно как и широту в пространстве (Я не научусь это делать ни при каких обстоятельствах). Все три показателя отмечаются знаком «минус». Остальные показатели оценки во фразе не представлены, поэтому отмечены знаком «0». Итоговая оценка фразы - «минус 4», что соответствует пессимистичному восприятию фразы и с нашей точки зрения является неэффективной реализацией тактики «критика недостатков», так как не только не способствует формированию оптимистического восприятия учебных ситуаций, но и усугубляет негативное состояние студента, испытывающего состояние выученной беспомощности.

Эффективность реплики с точки зрения студента с оптимистичными взглядами на жизнь в данной работе не оценивалась.

Виды речевых стратегий и тактик, а также их речевая актуализация заимствованы из статьи Агиенко М. И., Рольгайзер А.А. Речевые тактики осуществления функции педагогического контроля в современном вузе: междисциплинарный подход //Концепт. - 2018. - №. 3. - С. 175-187.

Виды речевых стратегий и тактик, а также их речевая актуализация заимствованы из статьи Агиенко М. И., Рольгайзер А.А. Речевые тактики осуществления функции педагогического контроля в современном вузе: междисциплинарный подход //Концепт. - 2018. - №. 3. - С. 175-187. 
International Journal of Scientific and Technological Research ISSN 2422-8702 (Online), DOI: 10.7176/JSTR/6-05-05

Vol.6, No.5, 2020 www.iiste.org

ISTE

\section{Оценивающая стратегия преподавателя}

\begin{tabular}{|c|c|c|c|c|c|c|c|c|c|c|}
\hline \multirow{5}{*}{ 莺 } & \multirow{5}{*}{$\begin{array}{c}\text { Речевая актуализация } \\
\text { тактики }\end{array}$} & \multicolumn{8}{|c|}{ Параметры оценки речевой актуализации } & \multirow{5}{*}{$\begin{array}{c}\text { Итоговая оценка } \\
\text { восприятия } \\
\text { Оптимистичная++ } \\
\text { Пессимистичная- }\end{array}$} \\
\hline & & \multicolumn{4}{|c|}{ Локус контроля над ситуацией } & \multicolumn{2}{|c|}{ Постоянство } & \multicolumn{2}{|c|}{ Генерализация } & \\
\hline & & \multicolumn{2}{|c|}{ Причина неудач } & \multicolumn{2}{|c|}{ Преодоление неудач } & \multirow{2}{*}{$\begin{array}{c}\text { широко во } \\
\text { времени } \\
-\end{array}$} & \multirow{2}{*}{$\begin{array}{c}\text { локальн } \\
\text { о во } \\
\text { времени }\end{array}$} & \multirow{2}{*}{$\begin{array}{c}\text { широко в } \\
\text { пространстве } \\
-\end{array}$} & \multirow{2}{*}{$\begin{array}{c}\text { локально в } \\
\text { пространстве } \\
+\end{array}$} & \\
\hline & & интернальный & $\begin{array}{l}\text { экстернальн } \\
\text { ый }\end{array}$ & интернальный & $\begin{array}{c}\text { экстернальный } \\
\text { - }\end{array}$ & & & & & \\
\hline & & - & + & + & - & - & + & - & + & \\
\hline 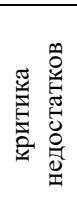 & $\begin{array}{c}\text { Вам следует } \\
\text { научиться правильно } \\
\text { распоряжаться своим } \\
\text { временем! }\end{array}$ & $\begin{array}{c}\text { - } \\
\text { Я не умею } \\
\text { распоряжаться } \\
\text { временем }\end{array}$ & 0 & $\begin{array}{c}- \\
\text { Мне следует этому } \\
\text { научиться, но я не } \\
\text { знаю, как это } \\
\text { сделать }\end{array}$ & - & $\begin{array}{c}- \\
\text { Я не умею и } \\
\text { никогда не } \\
\text { научусь } \\
\text { (базовая } \\
\text { установка) }\end{array}$ & 0 & $\begin{array}{c}- \\
\text { Я не научусь при } \\
\text { любых } \\
\text { обстоятельствах }\end{array}$ & 0 & $\begin{array}{l}- \\
- \\
- \\
- \\
-\end{array}$ \\
\hline 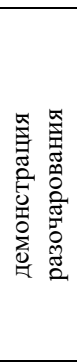 & $\begin{array}{c}\text { Мне жаль, что Вы } \\
\text { такой } \\
\text { безответственный } \\
\text { студент! }\end{array}$ & $\begin{array}{c}\text { - } \\
\text { Я еще и } \\
\text { безответственный } \\
!\end{array}$ & 0 & $\begin{array}{c}- \\
\text { Это моя вина! }\end{array}$ & 0 & $\begin{array}{c}- \\
\text { Всегда так! }\end{array}$ & 0 & $\begin{array}{c}\text { - } \\
\text { Возможно } \\
\text { сопротивление по } \\
\text { этому параметру. } \\
\text { Есть люди в } \\
\text { ближайшем } \\
\text { окружении } \\
\text { (друзья), которые } \\
\text { думают иначе! } \\
\text { Возможен } \\
\text { конфликт }\end{array}$ & 0 & $\begin{array}{l}- \\
- \\
- \\
-\end{array}$ \\
\hline 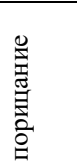 & $\begin{array}{c}\text { Вечно Вы } \\
\text { опаздываете на } \\
\text { лекции! }\end{array}$ & $\begin{array}{c}- \\
\text { Я - плохой } \\
\text { студент }\end{array}$ & 0 & $\begin{array}{c}- \\
\text { Я виноват }\end{array}$ & 0 & $\begin{array}{c}- \\
\text { Вечно так }\end{array}$ & - & 0 & - & $\begin{array}{l}- \\
- \\
- \\
-\end{array}$ \\
\hline 寓 & $\begin{array}{c}\text { Вы, как обычно, не } \\
\text { выполнили домашнее } \\
\text { задание }\end{array}$ & $\begin{array}{c}\text { Я - плохой } \\
\text { студент }\end{array}$ & 0 & $\begin{array}{c}\text { - } \\
\text { Это моя вина! }\end{array}$ & 0 & $\begin{array}{c}- \\
\text { «как } \\
\text { обычно»= } \\
\text { всегда }\end{array}$ & $\begin{array}{c}\text { - } \\
\text { не } \\
\text { сделано } \\
\text { и сейчас }\end{array}$ & 0 & $\begin{array}{c}- \\
\text { не сделано «здесь» }\end{array}$ & $\begin{array}{l}- \\
- \\
- \\
-\end{array}$ \\
\hline 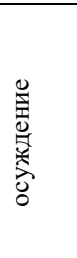 & $\begin{array}{c}\text { Нужно было не с } \\
\text { соседом по парте } \\
\text { разговаривать, а } \\
\text { преподавателя } \\
\text { внимательно } \\
\text { слушать! }\end{array}$ & Я-плохой студент & 0 & $\begin{array}{c}\text { - } \\
\text { Это моя вина! }\end{array}$ & 0 & 0 & - & 0 & $\begin{array}{c}- \\
\text { Возможно } \\
\text { сопротивление по } \\
\text { этому параметру. } \\
\text { Сохранить лицо } \\
\text { перед соседом за } \\
\text { то, что его подвел. } \\
\text { Конфликт! }\end{array}$ & $\begin{array}{l}- \\
- \\
- \\
-\end{array}$ \\
\hline
\end{tabular}

57 | P a g e

www.iiste.org 
International Journal of Scientific and Technological Research ISSN 2422-8702 (Online), DOI: 10.7176/JSTR/6-05-05

\section{Vol.6, No.5, 2020}

www.iiste.org

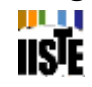

\begin{tabular}{|c|c|c|c|c|c|c|c|c|c|c|}
\hline 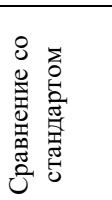 & $\begin{array}{c}\text { Вы сделали задание } \\
\text { очень хорошо, как и } \\
\text { следовало! }\end{array}$ & - & 0 & 0 & - & 0 & + & 0 & 0 & - \\
\hline 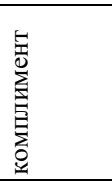 & $\begin{array}{c}\text { Вы очень хороший } \\
\text { студент! }\end{array}$ & 0 & 0 & $\begin{array}{c}\text { - } \\
\text { Я же неудачник }\end{array}$ & $\begin{array}{l}\text { Все, кто думает } \\
\text { иначе, -плохие } \\
\text { преподаватели. }\end{array}$ & + & $\begin{array}{c}- \\
\text { Похвала } \\
\text { временна }\end{array}$ & 0 & 0 & $\begin{array}{l}- \\
+ \\
-\end{array}$ \\
\hline 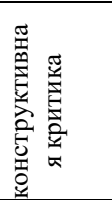 & $\begin{array}{c}\text { На мой взгляд, } \\
\text { работу можно было } \\
\text { сделать лучше. Мне } \\
\text { Ваш проект видится } \\
\text { так... }\end{array}$ & - & 0 & + & 0 & 0 & + & 0 & + & - \\
\hline 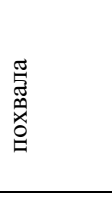 & \begin{tabular}{|c} 
Вы постарались, и \\
Ваши усилия \\
увенчались успехом - \\
это очень интересное \\
решение данной \\
задачи! \\
\end{tabular} & 0 & 0 & $\begin{array}{c}+ \\
\text { Я могу справиться } \\
\text { с трудностями! }\end{array}$ & 0 & 0 & + & 0 & + & + \\
\hline 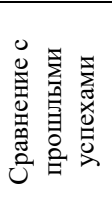 & \begin{tabular}{|c} 
Вы занимались, и \\
ваше произношение \\
значительно \\
улучшилось по \\
сравнению с \\
прошлым семестром
\end{tabular} & 0 & 0 & $\begin{array}{c}+ \\
\text { Я могу исправить } \\
\text { ситуацию }\end{array}$ & 0 & 0 & + & 0 & + & + \\
\hline
\end{tabular}

Из таблицы видно, что тактики отрицательной оценки, особенно критика недостатков и поведения и критика с элементами разочарования «наблюдателя» могут нести наиболее опасные последствия для личности студента с синдромом выученной беспомощности. Усиление категоричности высказывания модусом модальности «Вам следует научиться правильно распоряжаться своим временем!» вносит негативный элемент экстернальности в параметр «Преодоление неудач». Это приучает к мысли о наличии внешнего контроля, которого студент в состоянии выученной беспомощности обычно стремится избежать. Тактика «сравнение со стандартом», при всей своей комплиментарности, также скорее демотивирует студента. Исследования М. Райана и Э. Деси показали, что тактика равнения на стандарт приводит к снижению мотивации учащихся относительно выполнения тех заданий, которые они выполняют с удовольствием. Не одинаково эффективными являются и тактики положительной оценки (похвала и комплимент). Личностно-ориентированная похвала противоречит базовым установкам выученной беспомощности, провоцируя, скорее всего, пассивное ответное поведение студента. Зону максимальной мотивации, очевидно, может обеспечить только похвала усилий или конструктивная критика с элементами помощи. 
International Journal of Scientific and Technological Research ISSN 2422-8702 (Online), DOI: 10.7176/JSTR/6-05-05

Vol.6, No.5, 2020 www.iiste.org

ISTE

\section{Контролирующая стратегия преподавателя}

\begin{tabular}{|c|c|c|c|c|c|c|c|c|c|c|}
\hline \multirow{5}{*}{ 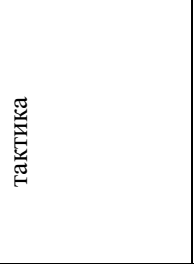 } & \multirow{5}{*}{$\begin{array}{c}\text { Речевая } \\
\text { актуализация } \\
\text { тактики }\end{array}$} & \multicolumn{8}{|c|}{ Параметры оценки речевой актуализации } & \multirow{4}{*}{$\begin{array}{c}\text { Итоговая оценка } \\
\text { восприятия } \\
\text { Оптимистичная+/ } \\
\text { Пессимистичная- }\end{array}$} \\
\hline & & \multicolumn{4}{|c|}{ Локус контроля над ситуацией } & \multicolumn{2}{|c|}{ Постоянство } & \multicolumn{2}{|c|}{ Генерализация } & \\
\hline & & \multicolumn{2}{|c|}{ Причина неудач } & \multicolumn{2}{|c|}{ Преодоление неудач } & \multirow{2}{*}{$\begin{array}{c}\text { широко во } \\
\text { времени } \\
-\end{array}$} & \multirow{2}{*}{\begin{tabular}{|c|} 
локально \\
во времени
\end{tabular}} & \multirow{2}{*}{$\begin{array}{c}\text { широко в } \\
\text { пространстве } \\
-\end{array}$} & \multirow{2}{*}{$\begin{array}{c}\text { локально в } \\
\text { пространстве } \\
+\end{array}$} & \\
\hline & & интернальный & экстернальный & интернальный & $\begin{array}{c}\text { экстернальный } \\
-\end{array}$ & & & & & \\
\hline & & - & + & + & - & - & + & - & + & \\
\hline 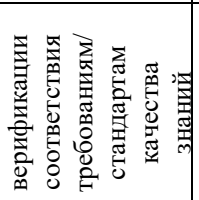 & $\begin{array}{c}\text { Работа (не) } \\
\text { соответствует всем } \\
\text { требованиям... } \\
\end{array}$ & $\begin{array}{c}- \\
\text { Мне не везёт }\end{array}$ & 0 & 0 & $\begin{array}{c}- \\
\text { Требования } \\
\text { ограничивают } \\
\text { мою свободу }\end{array}$ & $\begin{array}{c}- \\
\text { Всегда что- } \\
\text { нибудь не то с } \\
\text { моей работой }\end{array}$ & 0 & $\begin{array}{c}- \\
\text { Требования } \\
\text { всегда не } \\
\text { понятны }\end{array}$ & 0 & $\begin{array}{l}- \\
- \\
- \\
-\end{array}$ \\
\hline 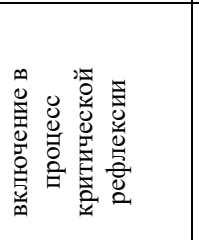 & $\begin{array}{c}\text { Как Вы думаете, в } \\
\text { каком месте Ваша } \\
\text { система первый раз } \\
\text { даст сбой? }\end{array}$ & 0 & $\begin{array}{c}+ \\
\text { Система имеет } \\
\text { недостатки }\end{array}$ & $\begin{array}{c}+ \\
\text { Я могу это } \\
\text { исправить. Система } \\
\text { уже составлена }\end{array}$ & 0 & 0 & $\begin{array}{c}+ \\
\text { Недостаток } \\
\text { временен }\end{array}$ & 0 & $\begin{array}{c}+ \\
+ \\
\text { Недостаток в } \\
\text { системе }\end{array}$ & $\begin{array}{l}+ \\
+ \\
+ \\
+\end{array}$ \\
\hline 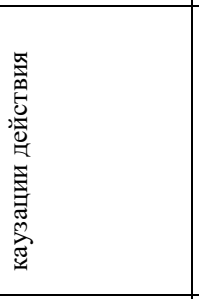 & $\begin{array}{c}\text { Продемонстрируйт } \\
\text { е ваши знания в } \\
\text { ходе решения кейс- } \\
\text { стади }\end{array}$ & $\begin{array}{c}- \\
\text { Я не смогу }\end{array}$ & 0 & $\begin{array}{c}- \\
\text { Я многого не знаю }\end{array}$ & 0 & 0 & + & 0 & + & $\begin{array}{c}+ \\
+ \\
- \\
\text { Все, что вы узнали } \\
\text { из параграфа, вам } \\
\text { пригодится при } \\
\text { решении кейс-стади }\end{array}$ \\
\hline 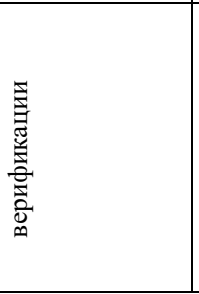 & $\begin{array}{c}\text { Обоснуйте Ваш } \\
\text { ответ конкретными } \\
\text { примерами }\end{array}$ & $\begin{array}{c}\text { - } \\
\text { Я не смогу }\end{array}$ & 0 & Я многого не знаю & 0 & 0 & + & 0 & + & $\begin{array}{c}- \\
- \\
+ \\
+ \\
\text { Постарайтесь } \\
\text { /Теперь вы можете } \\
\text { обосновать ваш } \\
\text { ответ конкретными } \\
\text { примерами }\end{array}$ \\
\hline
\end{tabular}


International Journal of Scientific and Technological Research ISSN 2422-8702 (Online), DOI: 10.7176/JSTR/6-05-05

Vol.6, No.5, 2020 www.iiste.org

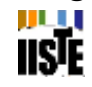

\begin{tabular}{|c|c|c|c|c|c|c|c|c|c|c|}
\hline 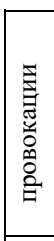 & $\begin{array}{c}\text { Вы уверены в том, } \\
\text { что это сочетание } \\
\text { слов переводится } \\
\text { именно так? }\end{array}$ & $\begin{array}{c}- \\
\text { Я не уврен }\end{array}$ & 0 & $\begin{array}{c}- \\
\text { Я многого не знаю }\end{array}$ & 0 & 0 & + & 0 & + & $\begin{array}{c}- \\
- \\
+ \\
+ \\
\text { Давайте проверим, } \\
\text { так ли переводится } \\
\text { это словосочетание } \\
\end{array}$ \\
\hline 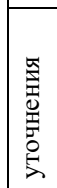 & $\begin{array}{c}\text { Вы действительно } \\
\text { так считаете? Вы } \\
\text { сказали, что ... }\end{array}$ & 0 & 0 & + & 0 & 0 & + & 0 & + & $\begin{array}{l}+ \\
+ \\
+\end{array}$ \\
\hline
\end{tabular}

Согласно результатам оценки, наименее эффективной тактикой контроля является тактика верификации соответствия требованиям/стандартам качества знаний. Формулировки, имплицирующие внешний контроль над ситуацией, усугубляют тревожность, присущую студентам с выученной беспомощностью, которые стараются избежать любого внешнего контроля. Такие формулировки усугубляют отчужденность к процессу обучения и не способствуют повышению мотивации. Наиболее эффективными тактиками представляются тактики включения в процесс критической рефлексии и тактики уточнения. Предложение преподавателя еще раз обдумать результаты сделанной работы или уже сказанное студентом переносят акцент с недостатков личности на недостатки работ (внешние причины неудачи), также сужают масштабы параметров «постоянство» и «генерализация», приближая, таким образом, параметры оценки ситуации к оптимистически ориентированному. 
International Journal of Scientific and Technological Research ISSN 2422-8702 (Online), DOI: 10.7176/JSTR/6-05-05

Vol.6, No.5, 2020 www.iiste.org

IISE

\section{Содействующая стратегия преподавателя}

\begin{tabular}{|c|c|c|c|c|c|c|c|c|c|c|}
\hline \multirow{5}{*}{ 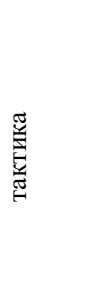 } & \multirow{5}{*}{$\begin{array}{c}\text { Речевая актуализация } \\
\text { тактики }\end{array}$} & \multicolumn{8}{|c|}{ Параметры оценки речевой актуализации } & \multirow{4}{*}{$\begin{array}{l}\text { Итоговая оценка } \\
\text { восприятия } \\
\text { Оптимистичная+/ } \\
\text { Пессимистичная- }\end{array}$} \\
\hline & & \multicolumn{4}{|c|}{ Локус контроля над ситуацией } & \multicolumn{2}{|c|}{ Постоянство неудачи } & \multicolumn{2}{|c|}{ Генерализация неудачи } & \\
\hline & & \multicolumn{2}{|c|}{ Причина неудач } & \multicolumn{2}{|c|}{ Преодоление неудач } & \multirow{2}{*}{$\begin{array}{c}\text { широко во } \\
\text { времени } \\
-\end{array}$} & \multirow{2}{*}{$\begin{array}{c}\text { локальн } \\
\text { о во } \\
\text { времени }\end{array}$} & \multirow{2}{*}{$\begin{array}{c}\text { широко в } \\
\text { пространстве } \\
-\end{array}$} & \multirow{2}{*}{$\begin{array}{c}\text { локально в } \\
\text { пространстве } \\
+\end{array}$} & \\
\hline & & интернальный & $\begin{array}{c}\text { экстернальн } \\
\text { ый }\end{array}$ & интернальный & $\begin{array}{c}\text { экстернальны } \\
\text { й } \\
-\end{array}$ & & & & & \\
\hline & & - & + & + & - & - & + & - & + & \\
\hline 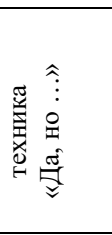 & $\begin{array}{c}\text { Да, вы полностью } \\
\text { раскрыли суть } \\
\text { поставленной } \\
\text { проблемы, но .. }\end{array}$ & $\begin{array}{c}- \\
\text { Беспокойство по } \\
\text { поводу } \\
\text { невысказанного } \\
\text { еще замечания, } \\
\text { ожидание } \\
\text { критики } \\
\end{array}$ & 0 & $\begin{array}{c}- \\
\text { Вдруг я не смогу?! }\end{array}$ & 0 & $\begin{array}{c}- \\
\text { Неизвестность, } \\
\text { предвидение } \\
\text { привычной } \\
\text { неудачи }\end{array}$ & 0 & $\begin{array}{c}- \\
\text { Неизвестность, } \\
\text { предвидение } \\
\text { привычной } \\
\text { неудачи }\end{array}$ & 0 & $\begin{array}{l}- \\
- \\
- \\
-\end{array}$ \\
\hline 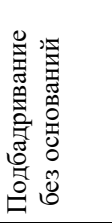 & Вы все можете! & Я '- & 0 & Я & 0 & - & 0 & - & 0 & $\begin{array}{l}- \\
- \\
- \\
-\end{array}$ \\
\hline 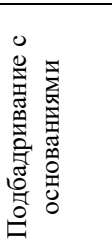 & \begin{tabular}{|c|} 
Вы лучше \\
подготовитесь к \\
следующему занятию \\
и получите более \\
высокую оценку.
\end{tabular} & Я & 0 & Я & 0 & 0 & + & 0 & + & $\begin{array}{l}- \\
- \\
+ \\
+\end{array}$ \\
\hline 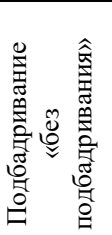 & \begin{tabular}{|c|} 
Сейчас, когда Вы \\
поняли эту тему \\
лучше, Вы \\
чувствуете, что \\
можете справиться с \\
подобными \\
заданиями?
\end{tabular} & 0 & 0 & + & 0 & 0 & + & 0 & + & $\begin{array}{l}+ \\
+ \\
+\end{array}$ \\
\hline
\end{tabular}

61 | P a g e

www.iiste.org 
International Journal of Scientific and Technological Research ISSN 2422-8702 (Online), DOI: 10.7176/JSTR/6-05-05

Vol.6, No.5, 2020 www.iiste.org

IISE

\begin{tabular}{|c|c|c|c|c|c|c|c|c|c|c|}
\hline 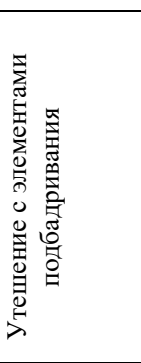 & \begin{tabular}{|c|} 
Это был Ваш первый \\
опыт выполнения \\
подобных работ, \\
который, к \\
сожалению, не \\
оправдал Ваших \\
ожиданий, но Вы \\
делали эту работу \\
самостоятельно, что \\
позволяет надеяться \\
на лучший результат \\
\end{tabular} & $\begin{array}{c}- \\
\text { Я многое делаю } \\
\text { неправильно }\end{array}$ & 0 & $\begin{array}{c}+ \\
\text { Я старался }\end{array}$ & 0 & 0 & + & 0 & + & $\begin{array}{l}- \\
+ \\
+ \\
+\end{array}$ \\
\hline 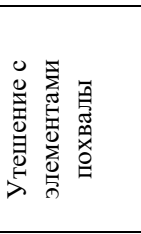 & \begin{tabular}{|c|} 
Несмотря на то, что в \\
Вашем эссе есть \\
ошибки, Вы \\
самостоятельно \\
справились с \\
заданием, и это \\
достойно похвалы \\
\end{tabular} & $\begin{array}{c}- \\
\text { Я часто делаю } \\
\text { ошибки }\end{array}$ & 0 & + & 0 & 0 & + & 0 & + & $\begin{array}{l}- \\
+ \\
+ \\
+\end{array}$ \\
\hline 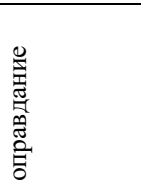 & $\begin{array}{c}\text { Сергей не подготовил } \\
\text { реферат в } \\
\text { установленные сроки } \\
\text { по причине болезни }\end{array}$ & 0 & + & 0 & - & 0 & + & 0 & + & $\begin{array}{l}- \\
+ \\
+ \\
+\end{array}$ \\
\hline 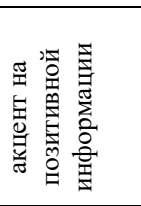 & \begin{tabular}{|c|} 
В вашей работе \\
представлена \\
подробная \\
классификация \\
фразеологизмов, что \\
нельзя не отметить \\
\end{tabular} & 0 & 0 & + & 0 & 0 & + & 0 & + & $\begin{array}{l}+ \\
+ \\
+\end{array}$ \\
\hline 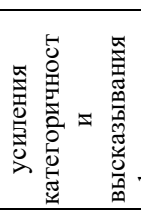 & $\begin{array}{c}\text { Вы должны понять } \\
\text { эту тему! }\end{array}$ & Я не смогу & 0 & 0 & $\begin{array}{c}- \\
\text { Это трудно! }\end{array}$ & $\begin{array}{c}\text { - } \\
\text { Я никогда } \\
\text { ничего не } \\
\text { пойму }\end{array}$ & 0 & 0 & + & $\begin{array}{l}- \\
+\end{array}$ \\
\hline
\end{tabular}

$62 \mid \mathrm{P}$ a g e

www.iiste.org 
Результаты оценки показывают, что самые неудачные тактики содействующей стратегии преподавателя - техника «Да, но ...» и подбадривание без оснований, которые усиливают неверие в собственные силы и способности в ситуации неопределенности, возвращая студента в знакомое и тревожное состояние дискомфорта, усиливая ощущение хронического ожидания неудачи в будущем, что создает предпосылки для дальнейшего развития состояния беспомощности.

Оптимизм студента может вызвать не новая попытка выполнить работу, а появившееся основание для успеха, например, самостоятельное освоение нового вида работ. Формулировки такого типа дают понять студенту, что успех выполнения работы зависит только от него самого, а неуспех локален во времени (на следующем занятии, тесте, проверочной работе) и локален в пространстве (правильное выполнение только этого типа задания/только по этой теме).

\section{Выводы:}

Как показывают результаты нашего исследования, самые распространенные реплики преподавателя несут пессимистический настрой. В лучшем случае они не ухудшают психологическое состояние студента. Как влияет пессимизм преподавателя на мотивацию оптимистически настроенных студентов группы еще предстоит выяснить. Но уже сейчас понятно, что в большинстве своем, необдуманные реплики укрепляют пессимистический стиль объяснения успехов и неудач студентов, испытывающих состояние выученной беспомощности, следовательно, сохраняют учебную мотивацию на уровне, свойственном этому состоянию.

Оценка параметров экологичности педагогического дискурса по предложенному методу всегда будет носить субъективный характер. Во-первых, потому, что мы вынуждены предвидеть и оценить еще не существующее, прогнозируемое восприятие слов педагога другой личностью. Вовторых, точность прогноза зависит от нескольких переменных - знаний интерпретатора, стабильности и благополучия его психоэмоциональной сферы (выученной беспомощности подвержены и педагоги), от сформированности эмоциональной компетенции педагога и от многих других факторов.

Однако такой параметрический подход к речи педагога нам представляется правомочным по нескольким причинам:

1) подлинным объектом педагогической психологии и является субъективная реальность, внутренний мир ученика, из которого он выстраивает свои отношения с объективной, в том числе и учебной, реальностью;

2) ставшая привычной для педагога оценка даже минимальной совокупности параметров собственной речи позволит привнести интеллектуальное начало в интуитивный компонент профессии, превратив его в профессиональный инструмент мотивации учебной деятельности студентов.

Эффективность педагогического дискурса невозможно построить «без эмпатического понимания другой стороны учебного диалога, без знания особенностей своего ... стиля, без сформированной эмоциональной корректности педагога, без правильно выстроенной системы «психологических координат» [Агиенко\&Рольгайзер: 184]. Профессионально решить проблему мотивации педагогу позволят и такие качества, как «видение проблемы там, где другие люди ее еще не видят; ...способность обращать внимание на необычные, порой кажущиеся незначительными события; готовность критически относиться к установленным общепринятым истинам и к новым идеям; умение создавать новые комбинации из известных сочетаний» [Маркова 1996].

\section{Литература:}

Anderman E. M., Wolters C. A. Goals, Values, and Affect: Influences on Student Motivation. - 2006.

Bandura, A. (1977). Self-efficacy: Toward a unifying theory of behavioral change. Psychological Review, 84, 191-215.

Deci E.L., Ryan R.M. Self-determination theory: A macrotheory of human motivation, development and health // Canadian Psychology. 2008. Vol. 49. P. 182 - 185.

Hiroto D. S. Locus of control and learned helplessness //Journal of experimental psychology. - 1974. - T. 102. - №. 2 .

Hiroto D. S., Seligman M. E. Generality of learned helplessness in man //Journal of personality and social psychology. - 1975. - T. 31. - №. 2.

63 | P a g e

www.iiste.org 
Phares E. J. Locus of control in personality. - Morristown, NJ : General Learning Press, 1976. - T. 174.

Rotter, J. B.(1966). Generalized expectancies for internal versus external control of reinforcement. Psychological Monograghs, 80 (1, Whole No. 609).

Seligman M.E.P., Weiss J. Coping behavior: Learned helplessness, physiological activity, and learned inactivity. Behavior Research and Therapy. 1980, 18,459512.

Valero A., Van Reenen J. The economic impact of universities: Evidence from across the globe //Economics of Education Review. - 2019. - T. 68. - C. 53-67.

Weiner B. Attribution theory, achievement motivation, and the educational process //Review of educational research. - 1972. - T. 42. - №. 2. - C. 203-215.

Weiner, B. A theory of motivation for some classroom experiences. Journal of Educational Psychology. - 1979. - 71(1). - 3-25.

Weiner, B. (2000). Intrapersonal and interpersonal theories of motivation from an attributional perspective. Educational Psychology Review. - 20000. - 12(1). - 1-14.

Агиенко М. И. Эмоциогенность новостного дискурса как фактор, влияющий на здоровье нации (к проблеме развития экологического интеллекта) //Язык и мышление: Психологические и лингвистические аспекты. - 2016. - С. 95-96.

Агиенко М. И., Рольгайзер А. А. Речевые тактики осуществления функции педагогического контроля в современном вузе: междисциплинарный подход //Концепт. -2018. - №. 3. - С 175-187.

Антонова Н. А. Педагогический дискурс: приемы диалогизации в речи учителя с целью оптимизации педагогического общения // Вопросы современной педагогики и психологии: свежий взгляд и новые решения: сборник научных трудов по итогам международной научно-практической конференции. - Екатеринбург, 2016. - С. 109-112.

Байшева С. А. Речевое выражение оптимизма и пессимизма в дневниках ЛН Толстого (1853, 1910 годы) //Язык и мышление: Психологический и лингвистический аспекты. Материалы. - 2005. C 146-151.

Балыкин А. И., Балыкина-Милушкина Т. В. Использование биологической обратной связи для выявления эмоционально нагруженных теоретических понятий в психологическом консультировании //Язык и мышление: психологические и лингвистические аспекты. 2017. - C. 99-101.

Верхозина О.А. Эмоции в межличностном педагогическом взаимодействии // Сибирский педагогический журнал. -2007. - № 14. - С. 412-420.

Волкова О. В. Особенности выученной беспомощности людей с разными характеристиками соматического здоровья: феноменология, технология исследования и система психологической помощи: автореф. дис. ... д-ра. психол. наук. Томск, 2018.

Воробьева, С. Ю. Экология дискурса: гендерный аспект / С. Ю. Воробьева // Вестник Волгоградского государственного университета. Серия 2, Языкознание. - 2013. - № 3 (19). - C. 204-212.

Выготский Л. С., Давыдов В. В. Педагогическая психология. - Педагогика-Пресс, 1996. - С. 536. 
Геранюшкина Г. П., Афраймович О. Э. Психологические защиты у лиц с признаками выученной беспомощности //Психология в экономике и управлении. - 2014. - №. 2. - С. 23-29.

Геранюшкина Г. П., Афраймович О. Э. Сценарии выученной беспомощности //Психология в экономике и управлении. - 2013. - №. 1. - С. 17-22.

Гордеева Т. О. Мотивация учебной деятельности школьников и студентов: структура, механизмы, условия развития: дис. ... д-ра. психол. наук. Москва, 2013.

Грановская Р. М., Крижанская Ю. С. Творчество и преодоление стереотипов. - 1994.

Гудина О. А. Манипуляция и ее виды в педагогическом дискурсе //Язык и культура. - 2011. №. 2 (14). C. 13-21.

Зиглер Д., Хьелл Л. Теории личности.- 3-е изд //СПб.: Питер. - 2009.

Ионова С. В. Основные направления эколингвистических исследований: современный и зарубежный опыт / С. В. Ионова // Вестник Волгоградского государственного университета. Серия 2, Языкознание. - 2010. - № 1 (11). - С. 86-93.

Казанцева Е. А. Влияние эмоциогенности педагогического дискурса на учебную мотивацию //Иностранные языки в современном мире. - 2017. - С. 135-140.

Казанцева Е. А. Особенности стратегий и тактик речевого воздействия в современном образовательном дискурсе //Филологические науки. Вопросы теории и практики. - 2018. №. 2-2 (80).

Казанцева Е. А. Эмоциональный фон педагогического дискурса: авторитет власти или власть авторитета? //Вестник УГНТУ. Наука, образование, экономика. Серия: Экономика. - 2017. - №. 1 (19).

Казанцева Е. А., Валиахметова Э. К., Минишева Л. В. Анализ учебной мотивации и отношения к изучению английского языка в Уфимском государственном университете экономики и сервиса //Вестник научных конференций. - ООО Консалтинговая компания Юком, 2016. №. 1-4. - С. 55-63.

Казанцева Е. и др. Социально-психологические факторы дисгармонизации педагогического дискурса //Вестник УГНТУ. Наука, образование, экономика. Серия: Экономика. - 2017. №. 3 (21). - C. 116-123.

Капрянцева Ю. В. Оптимистичность и пессимистичность высказываний в аспекте «локуса контроля» //Язык и мышление: Психологические и лингвистические аспекты. - 2015. - С. 43-48.

Карасик В. И. Характеристики педагогического дискурса // Языковая личность: аспекты лингвистики и лингводидактики. - Волгоград: Перемена, 1999. - С. 3-17.

Козлов В. В. Интегративная психология. - 2014.

Козлов В.В. Работа с кризисной личностью: метод. пособие. - 2-е изд. доп. - М.: Психотерапия, $-2007 .-336$ с.

Коменский Я. А. Избранные педагогические сочинения: В 2 т./Под ред. АИ Пискунова //М.: Педагогика. - 1982. - Т. 2. 
Котова Ю.В. Языковые аспекты классификации оптимистичных/пессимистичных высказываний // Вестник ЧелГУ. 2012. №28 (282). URL: https://cyberleninka.ru/article/n/yazykovye-aspekty-klassifikatsii-optimistichnyhpessimistichnyh-vyskazyvaniy дата обращения: 10.02.2020).

Котова Ю.В. Языковое выражение оптимизма/пессимизма в свете «Локуса контроля» // Известия ВГПУ. 2013. №6 (81). URL: https://cyberleninka.ru/article/n/yazykovoe-vyrazhenieoptimizma-pessimizma-v-svete-lokusa-kontrolya (дата обращения: 07.01.2020).

Котова Ю. В. Актуальность изучения языкового выражения оптимизма/пессимизма для теории языка //Вестник Ленинградского государственного университета им. АС Пушкина. - 2013-a. - T. 1. - №. 4. C. 114-120.

Крашенинникова И.В. Лингвоэкологические аспекты изучения современных массовых песен //Язык и мышление: Психологические и лингвистические аспекты. - 2018. - С. 132-134.

Крылова М. Н. Способы мотивации учебной деятельности студентов вуза //Перспективы науки и образования. - 2013. - №. 3. С.86-95.

Ларина Т. В. Эмотивная экологичность и эмотивная вежливость в английской и русской анонимной рецензии //Вопросы психолингвистики. - 2019. - №. 1 (39). - С. 38-59.

Левин К. Топология и теория поля // История психологии. XX век: Хрестоматия для высшей школы / Под ред. П.Я. Гальперина, А.Н. Ждан. М.: Академический Проект; Екатеринбург: Деловая книга, - 2005. - С. 236-246.

Леонтьев А.Н. Психологические основы развития ребенка и обучения. М.: Смысл, 2009.

Леонтьев В.В. Похвала в педагогическом дискурсе. https://www.researchgate.net/publication/318226062 Pohvala_v_pedagogiceskom diskurse Pr aising_in_pedagogical_discourse

Леонтьев Д.А. Общее представление о мотивации человека // Психология в вузе. 2004. № 1. С. 51-65.

Маркова А. К. Психология профессионализма. - М.: Международный гуманитарный фонд «Знание», 1996. - 312 с

Маркова А. К., Матис Т. А., Орлов А. Б. Формирование мотивации учения. - Акционерное общество «Издательство «Просвещение», 1990.

Маслоу А. Г. Мотивация и личность: [пер. с англ.]. - Издательский дом «Питер», 2009.

Олешков М. Ю. Моделирование коммуникативного процесса: монография. - Нижний Тагил: Нижнетагильская гос. социально-пед. акад., 2006. - 335 с.

Посохова С. Т. Оптимизм: психологическое содержание и личностный смысл //Вестник Санкт-Петербургского университета. Серия 12. Социология. - 2009. - №. 1.

Пузырёв А. В., Капрянцева Ю. В. Оптимистичность/пессимистичность как одна из характеристик языкового сознания //Язык и мышление: Психологические и лингвистические аспекты. - 2016. - С. 85-89.

Пузырёв А.В. Лингвофилософские аспекты Закона экономии усилий //Язык и мышление: Психологические и лингвистические аспекты. - 2018. - С. 93-104. 
Пузырёв А.В. Направленность хитовых песен радиостанций Европа+, Русское радио, радио DFM и Love Radio в 2012 г. // Язык и мышление поэта и писателя: Психологические и лингвистические аспекты: Материалы XIII-й Международной научной конференции (Ульяновск, 15-18 мая 2013 г.) / Отв. ред. проф. А.В.Пузырёв. - М.: Институт языкознания РАН; Институт русского языка РАН; Ульяновск: Ульяновский государственный университет, 2013. С. 54-62.

Пузырёв А.В. Об одной из важнейших проблем психологии, не вошедших в вузовские учебники. Материалы 6-ой Всероссийской научной конференции «Язык и мышление»: Психологический и лингвистический аспекты / Отв.ред.проф. А.В.Пузырёв. - М.; Ульяновск: Ин-т языкознания РАН; Ульяновский гос.ун-т, 2006. С. 85-100.

Ромек В. Г. Поведенческая психотерапия. Издательский центр «Академия».- 2002.

Селигман М. Путь к процветанию. Новое понимание счастья и благополучия. М.: Манн, Иванов и Фербер, 2013.

Селигман М. Как научиться оптимизму. М.: Альпина Нон-фикшн, 2013-а.

Селигман М. Новая позитивная психология: Научный взгляд на счастье и смысл жизни: пер. с англ. / М. Селигман. - М.: София, 2006. - 368 с.

Сердобинцева Е. Н. Законы общей экологии и язык //Экология русского языка: материалы. 2008. - C. 8-13.

Сердобинцева Е. Н. Экология русского языка // Материалы 1-й Всероссийской научной конференции. - Пенза: Издательство Пензенского государственного педагогического университета им. В. Г. Белинского, 2008.

Скворцова Т. А. К вопросу о гармонизации педагогического дискурса //Magister Dixit. - 2013. - №. 1.

Сковородников А. П. Лингвистическая экология или лингвоэкология //Культура русской речи: Энциклопедический словарь-справочник/под ред. Л.Ю. Иванова, А.П. Сковородникова, Е.Н. Ширяева. — М.: Флинта: Наука. - 2003.

Смирнов И.В. Психоэкология / И.В. Смирнов. - М., 2003. - 206 с.

Успенский В. Б., Чернявская А. П. Введение в психолого-педагогическую деятельность. 2003.

Ушинский К. Д. Собрание сочинений: в 8 т. / К. Д. Ушинский. - М.; Л.: Изд-во АПН СССР, 1950. - Т. 8. -769 с.

Цветкова Р. И. Мотивационная сфера личности студента: условия и средства ее формирования //Психологическая наука и образование. - 2006. - Т. 11. - №. 4. - С. 76-80.

Циринг Д.А. Феномен выученной беспомощности в онтогенезе личности: дис... канд. психол. наук. Челябинск, 2001.

Циринг Д.А., Эвнина К.Ю. Вопросы диагностики оптимизма и пессимизма в контексте теории диспозиционного оптимизма // Психологические исследования. 2013. Т. 6, № 31. С. 6. URL: http://psystudy.ru (дата обращения: 11.02.20).

Циринг, Д. А. Психология личностной беспомощности: автореф. дис. ... д-ра. психол. наук. Томск, 2010 
International Journal of Scientific and Technological Research

Шаховский В. И. Многоязычие стилей эмоционального медийного дискурса // Язык и мышление: психологические и лингвистические аспекты. - 2017. - С. 140-152.

Шаховский В.И. Экология эмотивного языка: теоретические и практические аспекты // Экология языка и коммуникативная практика. - 2013. - № 1. - С. 233-245.

Щербинина Ю. В. Педагогический дискурс. Мыслить-говорить-действовать. Учебное пособие. -2010. 